\title{
Cerebellar ataxia and nystagmus with GAD antibodies in a woman from the West Indies : a video demonstration
}

\author{
Kanterpersad Ramcharan (10 , ${ }^{1}$ Antonio J Reyes, ${ }^{2}$ Kamille Abdool, ${ }^{2}$ \\ Nitya Raamkaransingh ${ }^{3}$
}

Department of Medicine Neurology, SurgiMed Clinic, San Fernando, Trinidad and Tobago ${ }^{2}$ Department of Medicine, Neurology Unit, San Fernando Teaching Hospital, San Fernando, Trinidad and Tobago ${ }^{3}$ General Practitioner's Office, San Fernando, Trinidad and Tobago

Correspondence to Dr Kanterpersad Ramcharan, kramcharan79@yahoo.com

Accepted 30 August 2019

Check for updates

(C) BMJ Publishing Group Limited 2019. No commercial re-use. See rights and permissions. Published by BMJ.

To cite: Ramcharan $\mathrm{K}$ Reyes AJ, Abdool K, et al. BMJ Case Rep 2019:12:e231566. doi:10.1136/bcr-2019231566
A 72-year-old Afro-Caribbean woman presented with diplopia, vertigo, intermittent vomiting, progressively worsening ataxia (video 1) and nystagmus (video 2, segment 1 ) over a period of 4 months. There was a 2-year history of type 2 diabetes mellitus and hypothyroidism being treated with oral metformin $500 \mathrm{mg}$, gliclazide $80 \mathrm{mg}$ two times per day and L-thyroxine $0.1 \mathrm{mg}$ daily. She denied exposure to chemicals or recreational drugs. Social, family and sexual history were insignificant.

Her body mass index was $24 \mathrm{~kg} / \mathrm{m}^{2}$. The Mini Mental State Examination (MMSE) score was $30 / 30$. Cerebellar gait ataxia with an ample sustentation base was present. This worsened over 4 weeks, leading to a score of $26 / 40$ on the scale for the assessment and rating of ataxia (SARA). Dysmetria and dysdiadochokinesis were also prominent in all limbs. Bilateral gaze-evoked nystagmus was noted in the primary position, in horizontal, upbeat and down beat directions but this was not torsional (video 2, segment 1). Dysarthria, intention tremor, spinal cord long tract signs and rigidity were absent. The rest of the physical examination was normal.

Extensive medical investigations ruled out underlying endocrine, autoimmune, vasculitic, infectious and neoplastic illnesses. Glycosylated haemoglobin (Hb1Ac) level of 5.5\% was normal. Haematologic and metabolic status, hepatic and renal function tests, collagen vascular tests, tumour markers, retroviral and syphilitic serological tests and cerebellar antibody panel for neoplasm were normal. High levels of glutamic acid decarboxylase antibodies (GAD-Abs) at $502.4 \mathrm{U} / \mathrm{mL}$ (reference range positive above $10 \mathrm{U} / \mathrm{mL}$ ) with mildly elevated anti-thyroid antibodies (TPO $\mathrm{AB}$ ) at $37.18 \mathrm{IU} / \mathrm{mL}$

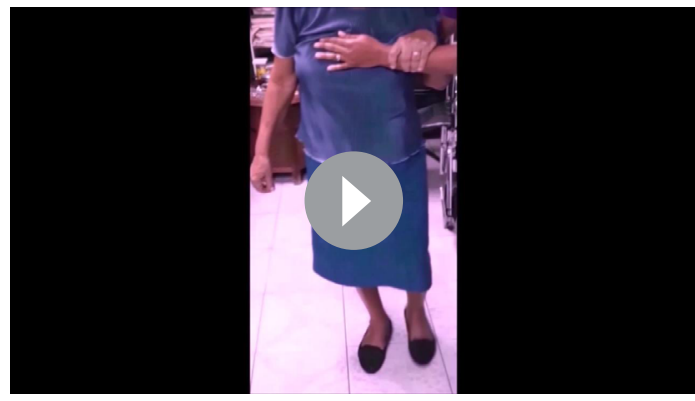

Video 1 Segment 1 showed moderate cerebellar ataxia with ample sustentation base and poor coordination on assisted ambulation. Segment 2 showed a positive dysmetria test.

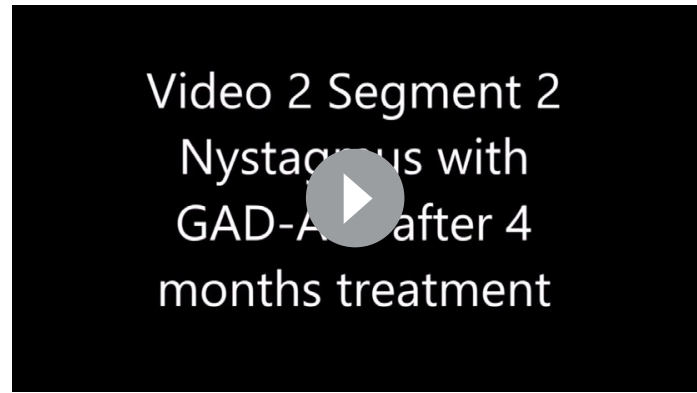

Video 2 Segment 1 recorded before treatment showed a jerk type severe bilateral nystagmus noted in the primary position and was of mixed directions such as horizontal, upbeat and down beat but not torsional. The nystagmus was not affected by the position of the patient's body. The phenomenon's periodicity was of approximately $60 \mathrm{~s}$. Segment 2 recorded 4 months after treatment showed a gazed-evoked bilateral nystagmus that were horizontal, upbeat and down beat but not torsional and was not seen in the primary eye position. There was an impaired gaze holding but no rebound, spontaneous peripheral vestibular phenomenon or Brun's nystagmus. There was a significant improvement in the severity, duration and impairment due to the phenomenon.

(reference range, 0-35 IU/mL) were noted. MRI of the brain with angiography and venography, MRI of the spinal cord, computerised tomographic scans of the chest, abdomen and pelvis, mammography, oesophgogastroduodenoscopy and colonoscopy were normal. Positron emission tomography scan and islet cell antibody testing were unavailable. Other immune-mediated cerebellar ataxias including gluten ataxia, paraneoplastic cerebellar degeneration, Hashimoto's encephalopathy and other differentials were also considered (table 1).

GAD-Abs associated cerebellar ataxia with nystagmus was diagnosed based on the neuroclinical manifestations, elevated serum GAD-Abs, MRI findings, exclusion of other diseases with further support from the patient's clinical and biochemical response to immunomodulation. Treatment with steroids and azathioprine over 4 months demonstrated an improvement of nystagmus (video 2, segment 2), partial resolution of diplopia, vertigo, dysmetria, dysdiadochokinesis and ataxia with an increase in the SARA score to 35/40. GAD-Abs level decreased to $318.4 \mathrm{U} / \mathrm{mL}$ after 6 months treatment. 
Table 1 Differential diagnosis and investigations

\begin{tabular}{|c|c|c|}
\hline Differential diagnosis & Investigation & Results and conclusion \\
\hline Stroke & History, T2W and DWI/ADC MRI & $\begin{array}{l}\text { Insidious onset of symptom, sudden vascular event unlikely, 4-month time needed to full } \\
\text { establishment of the syndrome. Upper motor, reflex and sensory examinations normal. No focal } \\
\text { lesions }\end{array}$ \\
\hline $\begin{array}{l}\text { Space occupying lesion of brain and } \\
\text { spine }\end{array}$ & T2W MRI & $\begin{array}{l}\text { No mass lesions. Minimal cerebral atrophy. No cerebellar atrophy. No evidence of intracranial } \\
\text { hypertension or middle shift }\end{array}$ \\
\hline Multiple sclerosis & T2W MRI & $\begin{array}{l}\text { No paraesthesia or sensory abnormalities. No evidence of demyelination disseminated in time/space } \\
\text { on MRI fails to satisfy MacDonald's criteria }\end{array}$ \\
\hline Multiple system atrophy & History, T2W MRI & $\begin{array}{l}\text { Autonomic features at presentation were absent and a pure cerebellar syndrome is not common } \\
\text { such as in our patient. The absence of typical MRI features such as 'hot cross bun sign' }\end{array}$ \\
\hline Paraneoplastic syndrome & $\begin{array}{l}\text { History, FDG-PET, onconeural } \\
\text { antibodies }\end{array}$ & No clinical pointer to malignancy. FDG-PET was not available. Onconeural antibodies were negative \\
\hline Inherited spinocerebellar ataxia & History, SCA6 genetic testing & $\begin{array}{l}\text { There were no signs of dysarthria, peripheral neuropathy, spasticity, areflexia, vegetative symptoms } \\
\text { or fasciculations. SCA6 Genetic testing was unavailable }\end{array}$ \\
\hline $\begin{array}{l}\text { A toxic or metabolic cerebellar } \\
\text { syndrome }\end{array}$ & History, biochemistry & $\begin{array}{l}\text { Unlikely without alcohol or recreational drugs consumption, exposure to chemicals or radiation, or } \\
\text { medication history (eg, lithium, phenytoin). Absent ophthalmoplegia is seen in thiamine deficiency } \\
\text { or areflexia and proprioception loss in vitamin E deficiency. Serum vitamin } B_{12^{\prime}} \text { folate levels and } \\
\text { haemoglobin were normal }\end{array}$ \\
\hline Creutzfeldt-Jacob disease & History & $\begin{array}{l}\text { No additional features such as rapidly progressive dementia, psychiatric disturbance, myoclonus and } \\
\text { sensory symptoms }\end{array}$ \\
\hline Hashimoto's encephalopathy & $\begin{array}{l}\text { History, GAD-Abs, anti-thyroid } \\
\text { antibodies }\end{array}$ & $\begin{array}{l}\text { Steroid-responsive encephalopathy with autoimmune thyroiditis that could not be confirmed by } \\
\text { elevation of anti-TPO or anti-thyroid microsomal antibody and/or anti-thyroglobulin. No additional } \\
\text { features such as seizures, myoclonus or tremor, chorea, dystonia and psychosis. When ataxia is the } \\
\text { only manifestation, it can easily be missed or mistaken for degenerative ataxia, however GAD-Abs } \\
\text { were positive }\end{array}$ \\
\hline Autoimmune cerebellar syndrome & History, GAD-Abs & $\begin{array}{l}\text { Clinical manifestations were typical of the disease and were associated with nystagmus, } \\
\text { hypothyroidism and diabetes. GAD-Abs were strongly positive in serum. Consent for lumbar } \\
\text { puncture was not obtained }\end{array}$ \\
\hline
\end{tabular}

DWI/ADC MRI, diffusion-weighted imaging/ apparent diffusion coefficient magnetic resonance imaging; FDG-PET, fluorodeoxyglucose-positron emission tomography; GAD-Abs, glutamic acid decarboxylase autoantibody; SCA6, spinocerebellar ataxia type 6; T2W MRI, T2-weighted magnetic resonance imaging.

Subsequently, human immune globulin and/or plasmapheresis treatment was declined.

GAD-Abs spectrum disorder includes limbic encephalitis, opsoclonus-myoclonus-ataxia syndrome, palatal myoclonus, epilepsy, stiff person syndrome, encephalomyelitis with rigidity, Guillain-Barré and myasthenia like syndromes, cerebellar ataxia with or without nystagmus and is considered part of

\section{Learning points}

- Glutamic acid decarboxylase antibodies (GAD-Abs)associated cerebellar ataxia is a part of an expanding spectrum of neurological disorders associated with the GAD enzyme needed to convert the excitatory amino acid glutamate into the inhibitory neurotransmitter gammaaminobutyric acid.

- Cerebellar ataxia associated with GAD-Abs can be diagnosed based on the neuroclinical manifestations and elevated GAD-Abs, with further support from the patient's response to immunomodulation.

- Cerebellar ataxia with or without nystagmus associated with GAD-Abs is a potentially treatable syndrome using immunomodulation.

- GAD-Abs should be sought not only in patients with polymorphic, persistent or refractory neurological syndromes but also with associated cancer and polyglandular autoimmune illnesses. the group of polyglandular autoimmune illnesses, that includes diabetes mellitus, myasthenia gravis, thyroiditis and pernicious anaemia. The cerebrospinal fluid analysis may be normal or may show oligoclonal bands, mild pleocytosis and intrathecal synthesis of GAD-Abs, in some cases. Cerebellar ataxia associated with GAD-Abs is rare, particularly when accompanied by nystagmus. ${ }^{1-3}$

This report represents the first documented case of this clinical entity from the West Indies.

Contributors KR: conceived the manuscript. AJR: wrote the first draft and prepared the videos. KR, AJR, KA and NR: worked on subsequent revisions. All authors assume responsibility for the final manuscript.

Funding The authors have not declared a specific grant for this research from any funding agency in the public, commercial or not-for-profit sectors.

Competing interests None declared.

Patient consent for publication Obtained.

Provenance and peer review Not commissioned; externally peer reviewed.

\section{ORCID iD}

Kanterpersad Ramcharan http://orcid.org/0000-0003-2937-6362

\section{REFERENCES}

1 Aguiar TS, Fragoso A, Albuquerque CR, et al. Clinical characteristics of patients with cerebellar ataxia associated with anti-GAD antibodies. Arq Neuropsiquiatr 2017;75:142-6

2 Kuchling J, Shababi-Klein J, Nümann A, et al. GAD Antibody-associated late-onset cerebellar ataxia in two female siblings. Case Rep Neurol 2014;6:264-70.

3 Herard K, Khanni JL, Alusma-Hibbert K, et al. Neurological disorders associated with glutamic acid decarboxylase antibodies. Cureus 2019;11:e4738. 
Copyright 2019 BMJ Publishing Group. All rights reserved. For permission to reuse any of this content visit https://www.bmj.com/company/products-services/rights-and-licensing/permissions/

BMJ Case Report Fellows may re-use this article for personal use and teaching without any further permission.

Become a Fellow of BMJ Case Reports today and you can:

- Submit as many cases as you like

- Enjoy fast sympathetic peer review and rapid publication of accepted articles

Access all the published articles

Re-use any of the published material for personal use and teaching without further permission

Customer Service

If you have any further queries about your subscription, please contact our customer services team on +44 (0) 2071111105 or via email at support@bmj.com.

Visit casereports.bmj.com for more articles like this and to become a Fellow 